\title{
ESTABLISHING VALUES OF CHARACTER IN PHYSICAL EDUCATION LEARNING

\author{
Bafirman
}

Faculty of Sport Sciences

State University of Padang (UNP) Indonesia

bafirman@gmail.com

\begin{abstract}
Establishing character values at school has been done through variety of subjects including physical education. The values established only touch on the investment of the values not on the application in daily life yet. The research is characterized by research and development with qualitative and quantitative method. The expert validators; physical Education learning, phsycolog of learning analysis, and Indonesian language. The experiment design is pre test - post test controlled group design. The population is the elementary school students in Padang and the sample and respondent are detrmined through purposive sampling, that is: SDcore (core elementary school) and SD impacted (impacted elementary school) with 123 students of fifth grade. Collecting data is by using questionaire, observation, and interview. Data analysis is trhough descriptive statistical data in which the hypothesis is examined by covariance analysis and t-test. The research finding, (1) the establishing values influence significantly in physical Education learning for fifth grade students at SD core and impacted, (2) the establishing values affects significantly in physical Educationlearning between modificated and conventional model for fifth grade students of SD core and impacted.
\end{abstract}

\section{Key words}

establishing values of character, physical Education learning.

\section{Academic Discipline and Sub-Disciplines}

physical Education

TYPE (METHOD/APPROACH)

Research and Development

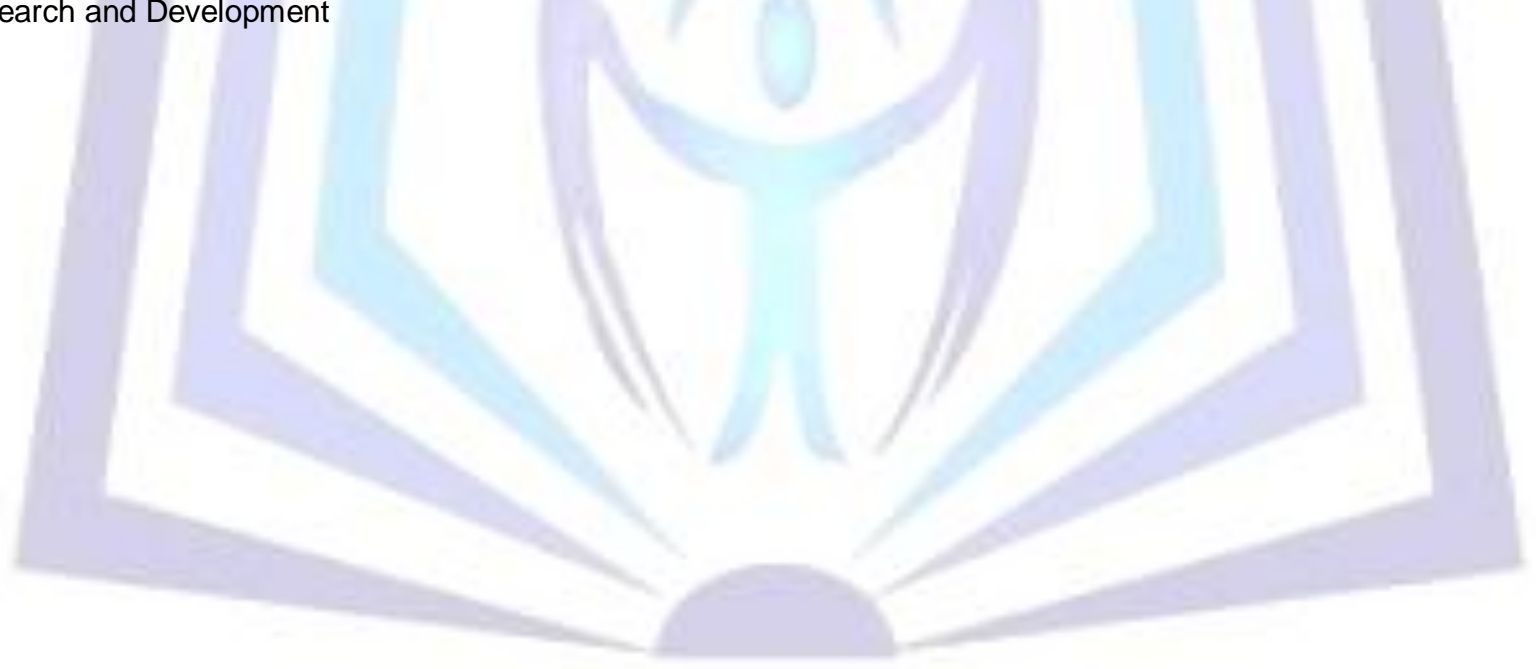

\section{Council for Innovative Research}

Peer Review Research Publishing System

\section{Journal: Journal of Social Sciences Research}

Vol .6, No.3

jssreditor.cir@gmail.com

www.jssronline.com 


\section{INTRODUCTION}

Physical education is an integral part of education entirely aiming to develop physical fitness aspect, movement skill, critical thinking skill. Social skill, emotional stability, moral attitude, intelectual activity, healthy life style aspect, and introducing the clean environment through physical activity. By doing so, Physical education makes holistic changing in individual quality either in physic, mental, or emotion for improving in mind and body than affect all of the students' daily life aspects.

Through a condusive physical activity in form of games and selected sport, the students are led well to develop their motion ability, so it can help them to grow up normally as stated in national education goals, that is: developing students' ability in order to be religious people toward god, good attitude, healthy, knowledgeable, skillful, creative, independent, and being democratic as well as responsible one (pasal 3 uu no.20 Sisdiknas tahun 2003).

Baron Pierre de Coubertin in Lutan; (2001) suggested that the goal of sports and physical Education lies in its role as a forum for improvement unk character, and as a way to own and form a strong personality, good character and noble nature; only those who have such moral virtues will be useful citizens ". This view reinforces the position Physical education as a vehicle for creating the expected human. Physical education have the competence to enhance the character and personality of the students in order to have good nature.

Along with globalization and progress information, character education has been neglected since an early age, then continues to the adolescence, adulthood, and even old age. It is seen any indication of the crisis that undermines the value of the individual character, communities and nations with a lifestyle that increasingly sacrificing moral importance. The younger generation was hit by the crisis of the great value that causes a variety of criminal activities that lead to the erosion of national character acknowledged the truth universally.

The values of civility has been reduced by the attitudes of inhumanity that entrenches in the form of student brawls, residents brawls, rape, murder, mutilation, suicide, abortion, alcoholism, involvement of community leaders in crime and corruption, overcoming violence with violence and so forth. Therefore, establishing the character values needs to be done in full, comprehensive, and integrated not only taught but must be intelligently establihed through the internalization of moral values, role models, and social control which is started from the the family institution, school, and community.

Ministry of Education (2011) developed a character education grand design for each track, level and type of education unit. The grand design becomes the conceptual and operational reference of development, implementation, and assessment on each lane and level of education. Configuring the characters in the totality context of the socio-cultural and psychological process are grouped into: (1) Spiritual and emotional development, (2) Intellectual development (3) Physical and kinestetic development; and, (4) Affective and Creativity development. Development and implementation of character education need to be done based on the grand design.

As stated previously, Physical education utilizes physic to develop human integrity and through physical activity, mental and emotional aspects are also helped to be developed causing improvements in the mind and body that affects all aspects of one's daily life. The holistical approach to body and soul may include an emphasis on three domains of education: psychomotor, cognitive and affective. Robert Gensemer (Freeman, 2001) said that Physical education is termed as the process of creating "a good body for a mind or soul".

In terms of policy, character education has been carried out in schools for a long time. Character education through a variety of subjects including the Learning Physical education so far just touches on the level of recognition norms or values, and not at the level of internalization and concrete actions in everyday life yet. Learning Physical education if well planned and executed is able to establish character education among learners because the values are implemented in the learning Physical education as delivering character values for learners if it is developed systematically.

Based on the various issues that have been raised, the reconstruction of the modified learning model physical education is believed to be an effective solution to instill character values to students.

\section{RESEARCH METHODE}

This research is the Research and Development with qualitative and quantitative methods. Validators of the research consist of the experts of Physical education learning, psychology of learning assessment, and Indonesian Language. The experimental design research is Pretest-Posttest Design Controlled Group. The population is the elementary school students in Padang. The schools and the respondent sample is determined by purposive sampling namely; Core SD and SD impact with 123 fifth grade students. The collection of research data through questionnaires, observation and interviews. Data were analyzed using descriptive statistical techniques, while the hypothesis was tested by analysis of covariance, and t-test.

\section{FINDINGS}

After doing the processing of descriptive data, it is proceeded with the testing requirements of data analysis through normality and homogeneity of variance tests. Testing for normality with Lilliefors test is revealed that the contribution of scores on establishing students character values as research subjects is normal, and by using Bartlet test population variance was actually taken from a homogeneous group.

The results of the research prove the hypothesis proposed; (1) The character values establishing significantly influencesat Physical education learning in fifth grade of elementary school students as Core school, with calculation of $p=0.00$ ( $p$ 
$<0.01$ ). (2) The values significantly influence in Physical education learning, when it is compared with conventional Physical education learning in fifth gradeof Coreelementary school students, with calculation of $p=0.00(p<0.01)$. (3) The values of character effectvery significantly in Physical education learning in fifth grade elementary students as impacted school, with calculation of $p=0.00(p<0.01)$. (4) The values of character influence very significantly Physical education learning, when it is compared with conventional Physical education learning in fifth grade os impacted elementary school students, with calculation of $p=0.00(p<0.01)$.

\section{DISCUSSION}

The result of hypothesis testing proves that the establishing character values to the learners through learning model of modificated Physical education in both treatment groups (SD Core and SD impact) provides a very significant effect. Through data processing, it is found thatestablishing character values to the learners treated through Physical education learning model is better than the students who are given the treatment of the conventional learning model.

A systematic process in developing learning is generally presented in the form of learning model. In the development of learning models, Sukmadinata (2004) suggested about the basis of selecting a lesson (approaches, models or procedures and methods of learning) are: learning objectives, characteristics of the subjects, the ability of students and teachers. Development learning model of modificated Physical education in establishing character values is done through a preliminary study phase, planning and development, as well as validation of the learning model based on learning as a system consisting of an input-process-output, relating to the design, implementation and evaluation and follow-up study.

Construction of character values that are implemented in Physical education, include the following; (1) Religious include; love God, love truth. (2) Smart includes; competent, control emotions, self-motivated and independent. (3) good moral; includes sportsmanship, ethics, courtesy and respect, humble, honesty, respect, responsibility and trust. (4) Generosity include; the kindness of others human beings, and helpful, caring and tolerant. (5) Competitive include; working hard, unyielding, confident, creative, orientation of excellence. (6) Leadership include; discipline, fairness and exemplary, and (7) Nationalism; includes love as a child Indonesia, love peace, national spirit and mutual assistance or cooperation.

Character values implemented in Physical education learning, according to the proposed Megawangi (2004) that the noble character education should be taught to children, which is then called the nine pillars, namely: (1) love God, trust, Reverence, loyalty), (2) responsibility, excellence, self-reliance, discipline, orderliness, (3) trustworthiness, realibility, honesty, (4) Respect, courtesy, obedience, (5) Love, caring compassion, empathy, generousity, moderation, cooperation. (6) confidence, assertivenss, creativity, resourfulness, courage, determination and enthusiasm, (7) Justice, fairness, mercy, leadership, (8) Kindness, friendliness, humility, modesty, and (9) Tolerance, flexibility, Peacefulness, unity.

The nine pillars of character are taught systematically in holistic education model using methods knowing the good, the good feeling, and acting the good. Knowing the good could be easily taught because knowledge is just cognitive. After knowing the good, it must be grown feeling loving the good, that is: how to feel and love the virtue of being the engine that could make students always want to do something good. Thus, it will create an awareness that people want to do a virtue behavior because he's in love with the virtue behavior. Once it is accustomed to do good, the acting good is turned into a habit.

Based on research findings, through the learning process, Physical education can instill a better character values to learners. Physical education learning can form the psychomotor domain, the cognitive domain, and also the affective domain that led to improvements in the 'mind and body' that affects all aspects of the daily life of learners. Suharjana (2011) suggested that Physical education is undoubtful media of its efficacy to build the character of the nation. The development of ethics, positive values, discipline, sportsmanship, quick in making decisions. Physical education also can be used as an arena to develop honesty, promote integrity, and develop a sense of respect for other people's social environment.

Student involvement in playing activities make students as a more effective one and roleactively in the social environment that will form;(1). Learning teamwork. Students learn to work together with others in a democratic society, develop personal discipline, respect for others, and have passion to work hard as well as sacrifice. (2). Learning to succeed. Life in a society is highly competitive, students will not always win but students will be successful when they are willing to work hard continuously, (3). Learning to play well. Through playing activities, it will be developed positive social attitudes that is; emotional control, honesty, cooperation, and interlinked with others, (4). Learning to enjoy physical activity. Each student will be happy in activity physically regardless of fatigue. This is because students do it with pleasure and excitement, (5). Learning healthy habits. Participation in active playing will be able to familiarize the student an active life.

\section{Establishing the values of character between the treatment and control groups at the core elementary school.}

Establishing the values of character Physical education to the students through modificated and conventional learning model in class $V$ Physical education SD core, between the treatment and control group, significantly influence with the calculation of $p=0.00(p<0.01)$. Specifically in the control group SD core, conventional Physical education learning affects significantly with $p=0.023(p<0.05)$ for the establishing of students character values. The increasing of students character values between treatment groups with the control SD Core is based on the following graph: 


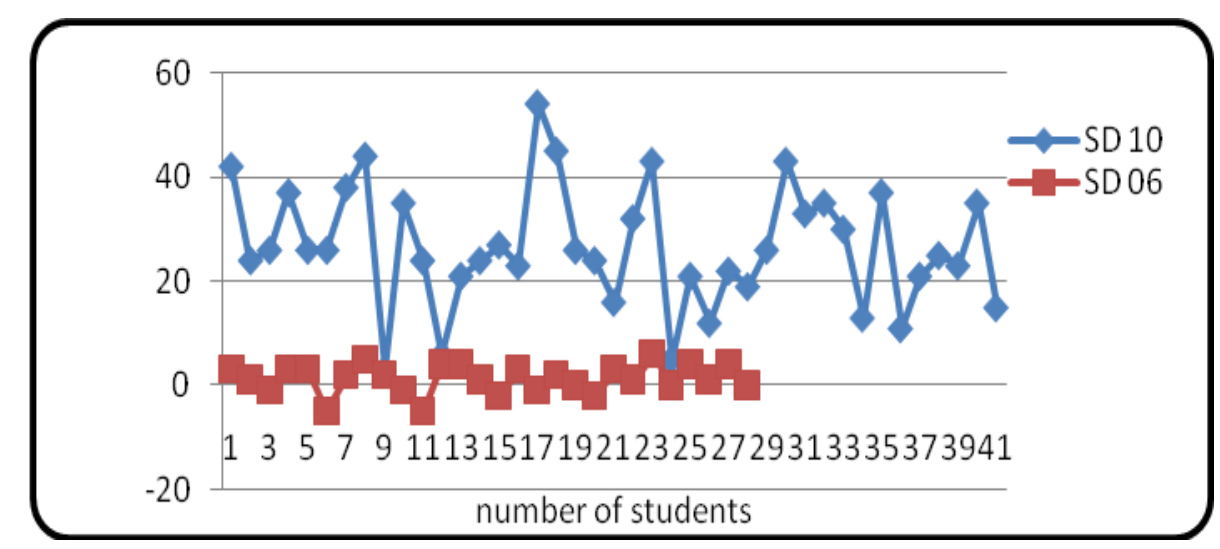

Chart 1. Establishment character values between treatment and control groups at the core elementary. (Bafirman, 20011).

Based on the graphabove, it means that the range of increasingcharacer value establishment of students through modificated learning model Physical education to the SD core (SD 10) is better than conventional Physical education learning (SD 06). This finding means that the modificated learning model Physical education performed on the SD core of learning is more effective than conventional Physical education for establishment character values to the learners.

The more effective modificated learning model Physical education to establish the values of character, in accordance with the standards regulation of the Ministry of Education 41/2007 includes; Planning the learning process, the implementation of the process of learning, and assessment of learning outcomes. In the process of modificated learning models Physical education, teachers' interaction with learners, as the primary meaning of the learning process, plays an important role to achieve the learning effective Physical education objectives.

\section{The establishment values of character between the treatment and control groups on SD impacted.}

The modified learning model Physical education is very influential significantly when compared with conventional Physical education study on the formation of students' character of class $\mathrm{V}$ between the group treated with the control at SD impacted, with calculation of $p=0.00(p<0.01)$. Specifically in the control group SD impacted, the conventional Physical education learning effect was significantly with $p=0.021(p<0.05)$, to the establishment of learners character values. The increasing establishment of students' character values between treatment groups with the control SD impacted fits the following graph:

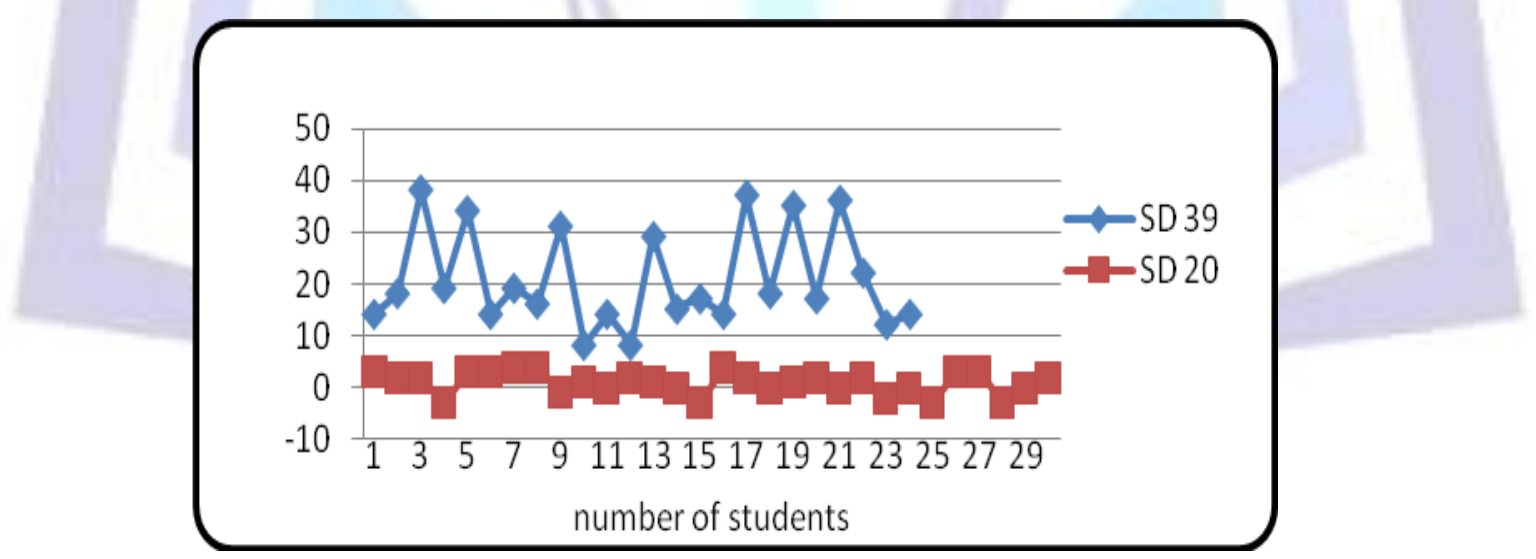

Chart 2. Establishment character values between treatment and control groups on the SD impacted (Bafirman, 20011).

In accordance with the graph above, the establishment of character values through modificated learning model of Physical education to SD impacted is also better. Modificated learning model of Physical education to the establishment of character values in SD impact (SD 39) is more influential compared with conventional Physical education learning (SD 20). This means modificated learning model of Physical education performed on the SD impacted is more effective than conventional Physical education learning to character value investment for the students.

Mutohir (2002) suggested that in the physical Education,there is a process of change in attitudes and behavior of a person / group in order to produce the mature business man through teaching and training efforts. Physic is the body (physically), but the question here is not only the body, but as a whole ( person entirely), because between the physical and the spiritual can not be separated, and constitute a unified whole that is always connected and mutually influential. 
Physical education is not just in the form of exercise that aims to nourish the body, but the inside is covered character formation purpose.

Physical education advantage in establishing the values of character is on the concretization of values into behaviors. It is a difficult trait to do on the other substances in the curriculum and learning that tends to be theoretical, abstract, and verbalistic. Through Physical education learning, it can becreated the character education among students systematically. It is certainly believed that Penjasorkes is a very powerful strategy for the developing the character and personality of the nation if it is developed systematically.

\section{The establishment of character values through modificated Learning Model of Physical education at SD Core and SD impacted}

The establishment of charactervalues to the learners through modificated learning model of Physical education to SD core and SD impactedis equally influentialsignificantly. The increasing character values between SD core and SD impactedis based on the following chart:

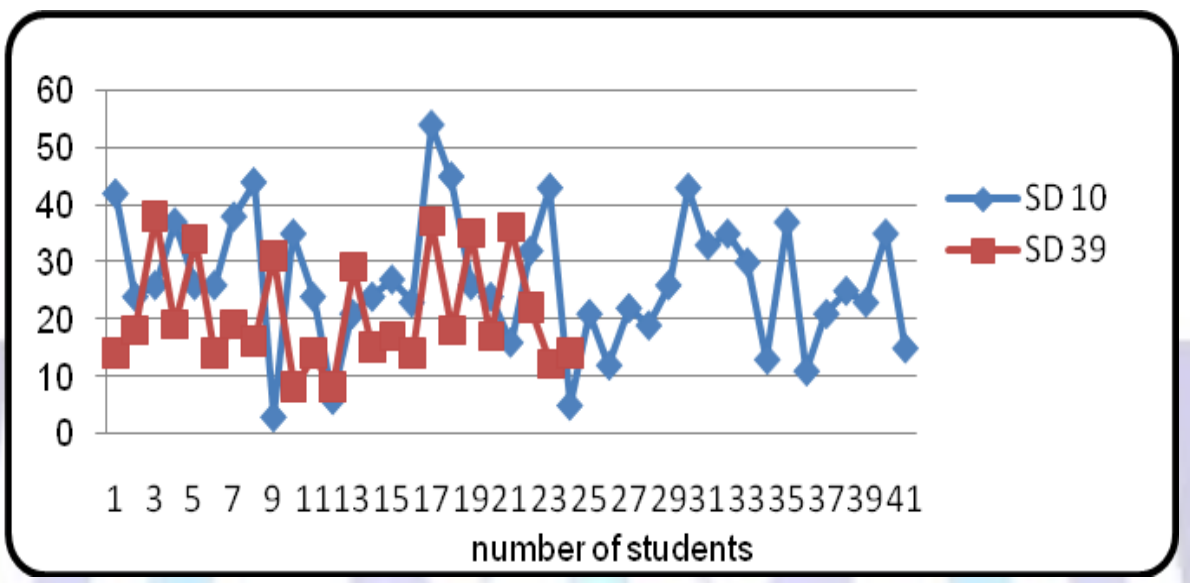

Chart 3. The values of character through modificated learning model of Physical education to SD core and SD impacted (Bafirman, 20011).

According to the chart above, establishment the character values to the students through modificated learning model of Physical education at SD Core and SD impacted is equally increased. The range of increasing in the establishmentthe character values for the students through modificated learning model of Physical education to SD core is better than SD impacted.

The modificated learning model Physical education is more influential to the establishment the character value for the students in SD core when compared to SD impact. This is affected by several factors, namely; the condition of infrastructure and facilities at the SD core is better than at the SD impacted. Physical education teachers at SD core have been already teaching for 25 years, while teachers in SD impacted teachfor 10 years. In addition, the condition of the school environment and the economic status of parents at SD core look better than at the SD impacted.

Learning Physical education in establishment character values for the studentis a conceptual framework describing a systematic procedure in organizing learning experiences to achieve learning objectives and serve as guidance in designing learning. According to Oliva (1992: 413) models of teaching are strategies based on theories (and often the research) of educators, psychologist, philosophers, and others who question how individual learn. This means that every learning model must contain a rationale based on the theory, containing a series of strategy waysapplied by the teachers and students, supported by systems or learning facilities, and methods to evaluate students' progress.

As previously stated, the Physical education means education programs through motion or play and excercise (sport). It means that movement, games, or certain sports are chosen merely a means to educate. Weinberg \& Gould (2003: 533) states that participation in an exercise program can instill character values, improve and educate one's moral analysis and sportsmanship. Lutan (2001) asserts that the ultimate goal of Physical education is on its role as a unique forum for the refinement of character and as a vehicle to form a strong and noble personality. Physical education content of the motion lessons as exercise activity is able to foster a culture of social devotionalism based on the values contained in sport tradition.

Physical education learning materials is related to norms or values that need to be developed, made explicit, associated with the context of daily life. The relation of moral values with sport practice and practice in life according to Ali Maksum (2009) is suitable with the following table: 
Table 1. Relation of moral values in sport practice and practice in life

\begin{tabular}{|c|c|c|}
\hline Moral value & Practice in sport & Practice in life \\
\hline Respect & $\begin{array}{l}\text { - Respect for the rules andtradition } \\
\text { - Respect for the opponent and official } \\
\text { - } \text { Respect for the victory and defeat }\end{array}$ & $\begin{array}{l}\text { - Respect for others } \\
\text { - Respect the property of others } \\
\text { - Respect for the environment and himself }\end{array}$ \\
\hline Responsibility & $\begin{array}{l}\text { - Readiness in doing something } \\
\text { - Diciplin in training and competition } \\
\text { - } \text { Cooperative with other players }\end{array}$ & $\begin{array}{ll}\text { - } & \text { Meets the duty } \\
\text { - } & \text { believable } \\
\text { - } & \text { self-control }\end{array}$ \\
\hline Care & $\begin{array}{l}\text { - Helping a friend in order to play well } \\
\text { - Helping a troubled friend } \\
\text { - Giving much praise, reducing criticism } \\
\text { - } \quad \text { Playing for the team, not himself }\end{array}$ & $\begin{array}{ll}\text { - } & \text { Empathetic } \\
\text { - } & \text { Forgiving } \\
\text { - } & \text { Putting a greater importance }\end{array}$ \\
\hline Honesty & $\begin{array}{l}\text { - Obey the rules } \\
\text { - } \quad \text { Loyal to the team } \\
\text { - }\end{array}$ & $\begin{array}{l}\text { - } \text { Having integrity } \\
\text { - Reliable } \\
\text { - } \text { Doing something well }\end{array}$ \\
\hline Fair & $\begin{array}{l}\text { - Fair on all players includingdifferent } \\
\text { - } \quad \text { Provide an opportunity forother players }\end{array}$ & $\begin{array}{ll}\text { - } & \text { Follow the rules } \\
\text { - } & \text { Tolerant to others } \\
\text { - } & \text { Willingness to share } \\
\text { - } & \text { Do not take advantage of the troubles of } \\
& \text { others }\end{array}$ \\
\hline Attitude & $\begin{array}{l}\text { - } \text { Being an example / model } \\
\text { - Encourage good behavior } \\
\text { - Strive for excellence }\end{array}$ & $\begin{array}{ll} & \text { Being an example / model } \\
\text { - } & \text { Encourage good behavior } \\
\text { - } & \text { Strive for excellence }\end{array}$ \\
\hline
\end{tabular}

(Ali Maksum, 2009;31).

The sixth the value can be defined as the following; (1) Respect is an attitude that pays attention to others and treatingthem kindly. Respectattitudeis characterized by treating others as people want to be treated; talking politely to anyone; respecting the existing rules in the family, school, and community, (2) Responsibility is the ability to give respond, feedback, or reaction i a good way. Responsible is characterized by doing what has been agreed seriously; admitting mistakes made without reason; giving the best of what is done, (3) Care is the willingness to give attention and love of neighbor. Care is characterized by treating others, self, and something with love, paying attention and listening carefully to others, and handling something with caution, (4) Honesty is an open attitude and trustworthy. Honestyis characterized by saying what it is, keeping promises, admitting mistakes, refusing to lie, cheat, and steal, (5) Fair is to be fair to do and treat something. Fair attitude is marked by enforcing the right of others, including him, willing to accept mistakes and bear the risk, and rejecting prejudiced, (6) Civilized is the basic attitude that is needed in a society about propriety, regularity, and kindness. Civilized is characterized by putting something in place and appreciating against the regularity.

Playing in Physical education lessons provides a concept for learners to take responsibility for the game. When there is a "dispute", the responsibility of children in this game can assist them in the development of moral. Excitement to see opponents as friends in the game is equally valuable and deserve the award. Justice involves no partiality and equally responsible.

Thus, the establishment of character values is not only on the cognitive level, but also touches on internalization, and real practice in the life of students in the daily life. It is in line with President Susilo Bambang Yudhoyono statement that the establishment of the nation's character can be done through sports. Furthermorehe said in a commemoration national sports day XXV held at the indoor tennis building Bung Karno Stadium in Jakarta, Tuesday (antara.co.id, 2008: 1) that through sports we can develop a national character, sportsmanship as well increase the unity of the nation.

According to Sukadiyanto (2011) Socialization through sport in Physical education will have an impact on the habits of learners to be obedient and submissive in applying the values found in the sport. The more embedded character values through learning Physical education, Suharjana $(2011 ; 25)$ suggested that Physical education is one medium that is unquestionable efficacy to establish the character of the nation. The development of ethics, positive values, dicipline, sportsmanship, fast in making a decision are the product of Physical education passed in a long process. Physical education can be also used as an way to develop honesty, promote integrity, and develop a sense of respect for other people's social environment.

\section{CONCLUSION}

Based on the findings above, it can be taken some conclusions; (1) modificated Physical education Learning Model is a model of learning Physical education in elementary school developed not only for the introduction of norms or values, but the emphasis is more on the internalization and action as a habit in students' daily life. (2) The establishment of character values are significantly influential in Physical education learning in fifth grade in SD core and SD impacted (3) The establishment of character values affects significantly on learning Physical education between the modified model with the conventional model of fifth grade students at SD core and SD impacted. 


\section{UTTERANCE THANK YOU}

Utterance thankyou from author to the experts who have given contribution in this writing:

Prof.Dr.Syafruddin, M.Pd. as a validation learning expert physical education, Dr.Marjohan, M.Pd.Kons, as a validation psychology field learning study and Dr. Ngusman,M.Pd, validation language axpert.

Badrial principal SDN No.10, and Herawati, S.Pd principal SDN 39, Kec.Kuranji, Ferdawati llyas,Ama.Pd. Principal SDN 20, Setnawarni,A.Md, principal SDN 06, and Nurisma K.S.Pd., principal SDN 11 Kec.Nanggalo kota Padang who have given the willingness of the place for implementation of this research.

Januardi Yusuf, S.Pd. and Irwan.J. physical education teacher SDN No.10, Anasrul physical education teacher SDN

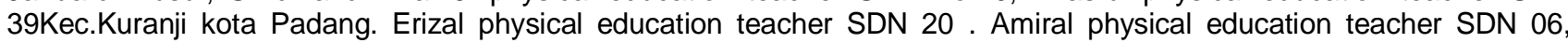
Kec.Nanggalo kota Padang who have helped as technical personnel in this research

\section{REFERENCES}

Ali Maksum. 2009. Konstruksi Nilai melalui Pendidikan Olahraga. Cakrawala Pendidikan, Februari 2009, Th. XXVIII, No. 1.

Antara. 2008. Bentuk Karakter Bangsa Melalui Olahraga. http://www.antara.co.id/arc/2008/9/9/presiden-bentuk-karakterbangsa-melalui-olahragal. 29 Oktober 2008.

Bafirman. 2011. Pembentukan Karakter dan Peningkatan Kualitas Kesegaran Jasmani Melalui Model Pembelajaran Pendidikan Jasmani Olahraga dan Kesehatan di Sekolah Dasar (Disertasi)

Elmubarok, Z.2008. Membumikan Pendidikan Nilai, Bandung: Alfabeta.

Freeman. 2001. physical Education and Sport in Changing Sociaty. New York: Macmillan Publishing Company.

Oliva, P.F. 1992. Developing the Curriculum. New York: Harper Collins.

Megawangi,R. 2004. Pendidikan Karakter, Jakarta: IHF.

Peraturan Menteri Pendidikan Nasional Republik Indonesia Nomor 41 Tahun 2007 Tentang Standar Proses Untuk Satuan Pendidikan Dasar dan Menengah Menteri Pendidikan Nasional,Ttd.Bambang Sudibyo.

Rusli Lutan. 2001. Olahraga dan Etika, Fair Play, Jakarta: Direktorat Pemberdayaan Ilmu Pengetahuan dan Teknologi Olahraga, Direktorat Jenderal Olahraga, Depertemen Pendidikan Nasional.

Suharjana. 2011. Model Pengembangan Karakter melalui Pendidikan Jasmani dan Olaharaga. Pendidikan Karakter dalam Perspektif Teori dan Praktek. Yokyakarta: UNY Press.

Sukadiyanto. 2011. Implementasi Pendidikan karakter dalam Pendidikan Jasmani dan Olahraga. Pendidikan Karakter dalam Perspektif Teori dan Praktek. Yokyakarta: UNY Press.

Sukmadinata, N.S. 2004. Kurikulum dan Pembelajaran Kompetensi.Bandung: Kesuma Karya.

Susilo Bambang Yudhoyono. 2006. Menata Kembali Kerangka Kehidupan Bernegara Berdasarkan Pancasila, Jakarta:

Suparlan, 2010. Pendidikan Karakter dan Kecerdasan.Website:www.suparlan.com; E-mail: me @ suparlan.co.id

Toho Cholik Muthohir. 2002. Gagasan-gagasan Tentang Pendidikan Jasmani dan Olahraga. Surabaya: Unesa University Press.

Undang-Undang Republik Indonesia Nomor 20 Tahun 2003 Tentang Sistem Pendidikan Nasional. www.hukumonline.com..hukumonline.com www.hukumonline.com.

Weinberg, Robert, S. \& Gould, Daniel. 2003. Foundation of Sport and Exercice Psychology. Champaign: Human Kinetics.

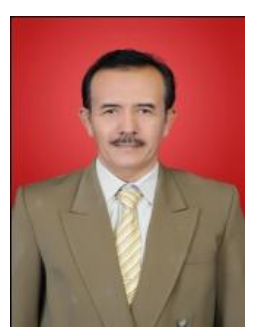

\section{Author Biography}

Bafirman was born in Nagari SungaiJambu ParianganTanah Datar District of West Sumatra province, in November $4^{\text {th }}$, 1959. He finished S1 degreeat the Department of physical Education and Health, Faculty of physical Education and HealthTeacher Training Institute Padang in 1983. Bafirman graduated S2 degree at Sports Health Sciences University of Airlangga (Airlangga University), Surabaya in 1996, and graduated S3 degree at Education Graduate Program, State University of Padangin 2011. Since October 1985 until now he servesas a faculty member of Recreationand Health Department FIK-UNP Padang 